\title{
Manufacturing Competitiveness Analysis for Hydrogen Refueling Stations
}

\author{
Ahmad Mayyas, Margaret Mann (P.I.) \\ National Renewable Energy Laboratory \\ June 14, 2018
}

DOE Hydrogen and Fuel Cells Program 2018 Annual Merit Review and Peer Evaluation Meeting

Project ID \# MN017

This presentation does not contain any proprietary, confidential, or otherwise restricted information. 


\section{Overview}

\section{Timeline}

- Project start date: April 2015

- Project end date: June 2018

- Percent complete: $90 \%$

\section{Budget}

- Total project funding

- DOE share: \$719 K

- Contractor share: n.a.

- Funding received in FY18: $\$ 0$

\section{Technical Barriers}

Cross-Cutting Fuel Cell Barriers

- F. Manual Stack Assembly

- I. Lack of Standardized Balance-of-Plant Component

Hydrogen Generation by Water Electrolysis

- F. Capital Cost

- K. Manufacturing

\section{Collaborators}

- Argonne National Laboratory

- Sandia National Laboratories

- Pacific Northwest National Laboratory

- Other Industry Advisors and Experts 


\section{Relevance \& Goals}

- To develop detailed bottom-up manufacturing cost analysis for key systems/parts in the hydrogen refueling station (HRS).

- To identify cost drivers for key systems in the hydrogen refueling stations (e.g., compressors, storage tanks, dispenser, coolers and heat exchanger)

- To identify cost drivers for onsite hydrogen production systems (PEM and alkaline electrolyzers)

- To investigate effect of economies of scale and learning experience on the cost of the onsite hydrogen production systems 


\section{Approach}

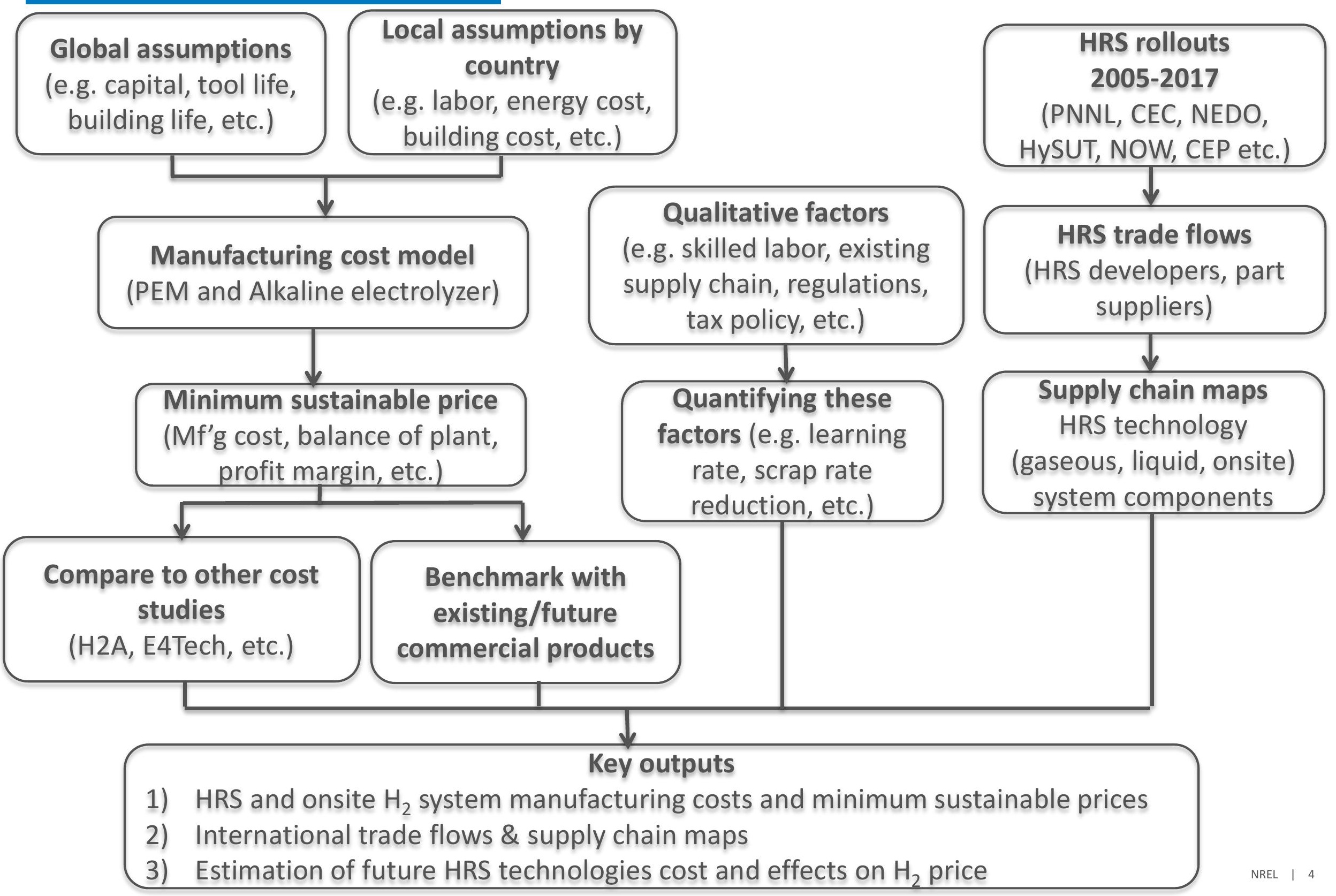




\section{Accomplishment- Global HRS Trade Flows}

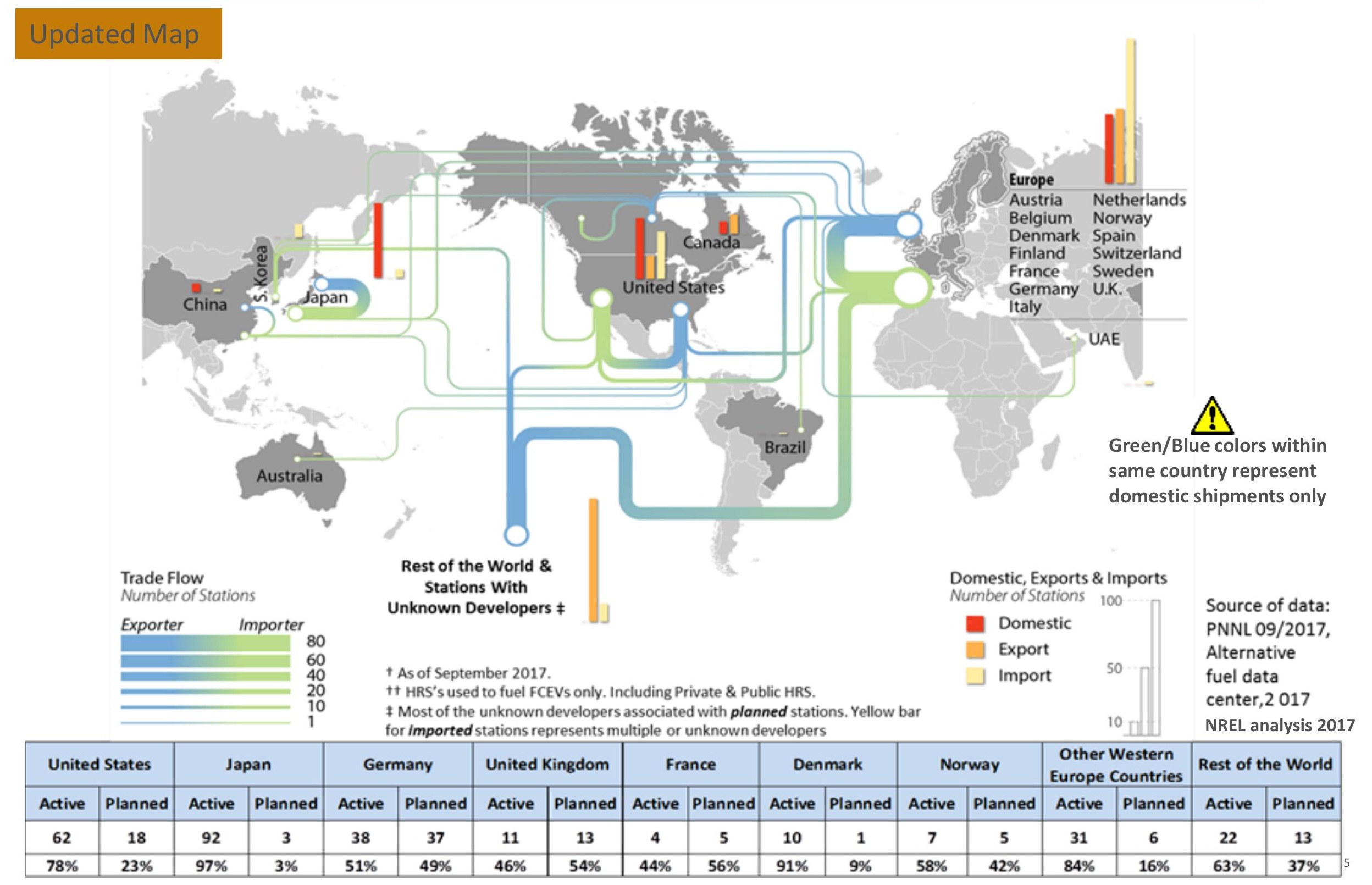




\section{Comparison Between PEM And Alkaline Electrolyzers}

PEM electrolyzers have larger current and power densities, shorter startup time and higher system price (in $\$ / k W)$

\begin{tabular}{|c|c|c|c|c|}
\hline Characteristics & Alkaline & PEM & Unit & Notes \\
\hline Current Density & $0.2-0.7$ & $1.0-2.2$ & $\mathrm{~A} / \mathrm{cm}^{2}$ & \\
\hline Power Density & $0.32-1.12$ & $1.4-3.52$ & $\mathrm{~W} / \mathrm{cm}^{2}$ & Reference voltage $=1.6$ volt \\
\hline Operating Temperature & $60-80$ & $50-84$ & ${ }^{\circ} \mathrm{C}$ & \\
\hline $\begin{array}{l}\text { Electricity Consumption } \\
\text { (Median) }\end{array}$ & $\begin{array}{l}50-73 \\
(53)\end{array}$ & $\begin{array}{l}47-73 \\
(52)\end{array}$ & $\mathrm{kWh} / \mathrm{kg}-\mathrm{H}_{2}$ & $\begin{array}{l}\text { Electrolysis system only. Excluding } \\
\text { storage, compression and } \\
\text { dispensing }\end{array}$ \\
\hline Min. Load & $20-40 \%$ & $3-10 \%$ & & \\
\hline Startup Time from Cold to Min. Load & $20 \min -60+$ & $5-15$ & minutes & \\
\hline $\begin{array}{l}\text { System Efficiency (LHV) } \\
\text { (Median) }\end{array}$ & $\begin{array}{l}45-67 \% \\
(63 \%)\end{array}$ & $\begin{array}{l}45-71 \% \\
(63 \%)\end{array}$ & & \\
\hline $\begin{array}{l}\text { System Lifetime } \\
\text { (Median) }\end{array}$ & $\begin{array}{l}20-30 \\
(26)\end{array}$ & $\begin{array}{l}10-30 \\
(22)\end{array}$ & Year & \\
\hline System Price & $\begin{array}{l}\$ 760-\$ 1,100 \\
(\$ 930)\end{array}$ & $\begin{array}{l}\$ 1,200-\$ 1,940 \\
(\$ 1,570)\end{array}$ & & $\begin{array}{l}\text { Including power supply, system } \\
\text { control and gas drying. Excluding } \\
\text { grid connection, external } \\
\text { compression, external purification } \\
\text { and } \mathrm{H}_{2} \text { storage }\end{array}$ \\
\hline
\end{tabular}




\section{PEM Electrolyzer System Design}

Stack is the core of the PEM electrolysis system. Balance of plant parts usually outsourced from reliable vendors

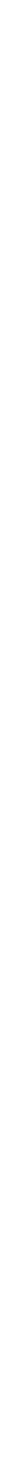




\section{Accomplishment- PEM Electrolyzer Functional Specifications for Analysis}

\section{Current and power densities are key parameters in the cell design}

\begin{tabular}{|c|c|c|c|c|c|c|c|c|c|c|c|}
\hline Stack Power & 10 & 20 & 50 & 100 & 200 & 500 & 1,000 & 2,000 & 5,000 & 10,000 & $\mathrm{~kW}$ \\
\hline single cell amps & \multicolumn{10}{|c|}{1224} & A \\
\hline current density & \multicolumn{10}{|c|}{1.80} & $\mathrm{~A} / \mathrm{cm}^{2}$ \\
\hline reference voltage & \multicolumn{10}{|c|}{1.619} & $\mathrm{~V}$ \\
\hline power density & \multicolumn{10}{|c|}{2.913} & $\mathrm{~W} / \mathrm{cm}^{2}$ \\
\hline Pt-Ir loading- Anode & \multicolumn{10}{|c|}{7.0} & $\mathrm{~g} / \mathrm{m}^{2}$ \\
\hline PGM loading Cathode & \multicolumn{10}{|c|}{4.0} & $\mathrm{~g} / \mathrm{m}^{2}$ \\
\hline single cell power & \multicolumn{10}{|c|}{1981.0} & W \\
\hline Cells per system & 5 & 10 & 25 & 50 & 101 & 252 & 505 & 1010 & 2524 & 5048 & cells \\
\hline stacks per system & 1 & 1 & 1 & 1 & 1 & 1 & 2 & 4 & 10 & 20 & stacks \\
\hline cells per stack & 5 & 10 & 25 & 50 & 101 & 252 & 252 & 252 & 252 & 252 & cells \\
\hline
\end{tabular}

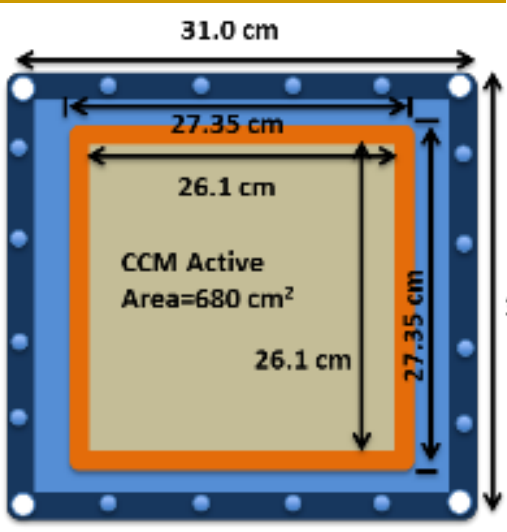

Plate area $=957 \mathrm{~cm}^{2}$

\begin{tabular}{|c|c|c|}
\hline Part & Assumptions & Notes \\
\hline Membrane & Nafion 117 (Purchased) & PFSA (PEEK, PBI) \\
\hline Pt & Pt-price $=\$ 1500 /$ tr.oz & DOE current value \\
\hline CCM & Spray Coating & $\begin{array}{l}\text { Platinum loadings: } \\
\text { Anode }=7 \mathrm{~g} / \mathrm{m}^{2}(\mathrm{Pt}) \\
\text { Cathode }=4 \mathrm{~g} / \mathrm{m}^{2} \text { (Pt-Ir) }\end{array}$ \\
\hline Porous Transport Layer & $\begin{array}{l}\text { Sintered porous titanium } \\
\text { Ti-price }=\$ 4.5 / \mathrm{kg}\end{array}$ & Porosity $=30 \%$ \\
\hline Seal/Frame & $\begin{array}{l}\text { Screen printed PPS-40GF or PEEK } \\
\text { seal }\end{array}$ & $\begin{array}{l}\text { Seal: } 0.635 \mathrm{~cm} \text { from each side for MEA } \\
\text { bonding }\end{array}$ \\
\hline Plates & Stamped stainless steel 316L & Coated plates (plasma Nitriding) \\
\hline
\end{tabular}




\section{Accomplishment- Alkaline Electrolyzer Functional Specifications for Analysis}

Current and power densities are key parameters in the cell design

\begin{tabular}{|c|c|c|c|c|c|c|c|c|c|c|c|c|}
\hline \multirow{15}{*}{ Stack } & Stack power & 10 & 20 & 50 & 100 & 200 & 500 & 1,000 & 2,000 & 5,000 & 10,000 & kW \\
\hline & $\begin{array}{l}\text { Avg. } \mathrm{H}_{2} \\
\text { production rate }\end{array}$ & 2 & 4 & 10 & 15 & 22 & 56 & 110 & 220 & 550 & 1,100 & $\mathrm{Nm}^{3} / \mathrm{bc}$ \\
\hline & $\begin{array}{l}\text { Avg. } \mathrm{H}_{2} \\
\text { production rate }\end{array}$ & 4 & 9 & 22 & 32 & 48 & 120 & 237 & 475 & 1,187 & 2,373 & $\mathrm{~kg} /$ day \\
\hline & Total plate area & \multicolumn{6}{|c|}{3,000} & \multicolumn{4}{|c|}{10,000} & $\mathrm{~cm}^{2}$ \\
\hline & $\begin{array}{l}\text { Total plate solid } \\
\text { area }\end{array}$ & \multicolumn{6}{|c|}{400} & \multicolumn{4}{|c|}{800} & $\mathrm{~cm}^{2}$ \\
\hline & $\begin{array}{l}\text { Electrode active } \\
\text { area }\end{array}$ & \multicolumn{6}{|c|}{2,600} & \multicolumn{4}{|c|}{9,200} & $\mathrm{~cm}^{2}$ \\
\hline & Electrolyte & \multicolumn{6}{|c|}{$\mathrm{H}_{2} \mathrm{O}+30 \% \mathrm{KOH}$} & \multicolumn{4}{|c|}{$\mathrm{H}_{2} \mathrm{O}+30 \% \mathrm{KOH}$} & $\mathrm{cm}^{2}$ \\
\hline & Single cell amps & 520 & 520 & 520 & 520 & 520 & 520 & 1840 & 1840 & 1840 & 1840 & A \\
\hline & Current density & 0.20 & 0.20 & 0.20 & 0.20 & 0.20 & 0.20 & 0.20 & 0.20 & 0.20 & 0.20 & $\mathrm{~A} / \mathrm{cm}^{2}$ \\
\hline & Reference voltage & 1.68 & 1.68 & 1.68 & 1.68 & 1.68 & 1.68 & 1.68 & 1.68 & 1.68 & 1.68 & v \\
\hline & Power density & 0.336 & 0.336 & 0.336 & 0.336 & 0.336 & 0.336 & 0.336 & 0.336 & 0.336 & 0.336 & $W / \mathrm{cm}^{2}$ \\
\hline & Single cell power & 873.6 & 873.6 & 873.6 & 873.6 & 873.6 & 873.6 & 3091.2 & 3091.2 & 3091.2 & 3091.2 & w \\
\hline & Cells per system & 12 & 23 & 58 & 115 & 229 & 573 & 324 & 647 & 1,618 & 3,235 & cells \\
\hline & Stacks per system & 1 & 1 & 1 & 1 & 2 & 3 & 2 & 4 & 9 & 17 & stacks \\
\hline & cells per stack & 12 & 23 & 58 & 115 & 115 & 191 & 162 & 162 & 180 & 191 & cells \\
\hline \multirow[t]{3}{*}{$\begin{array}{l}\text { Additional } \\
\text { Parasitic }\end{array}$} & $\begin{array}{l}\text { Air blower/ Liquid } \\
\text { pump }\end{array}$ & 0.3 & 0.5 & 1.5 & 2 & 3 & 7 & 10 & 15 & 30 & 50 & $\mathrm{~kW}$ \\
\hline & Other paras, loads & 0.2 & 0.3 & 0.5 & 1 & 1.5 & 3 & 5 & 8 & 10 & 15 & $\mathrm{~kW}$ \\
\hline & Parasitic loss & 0.50 & 0.80 & 2.00 & 3.00 & 4.50 & 10.00 & 15.00 & 23.00 & 40.00 & 65.00 & $\mathrm{~kW}$ \\
\hline
\end{tabular}

- Commercial alkaline electrolyzers can have large cells $(\sim 1.6 \mathrm{~m}$ in diameter ${ }^{\dagger}$ )

- Electrolyte solution (Water+30\% KOH)

\section{Functional Cell Design}

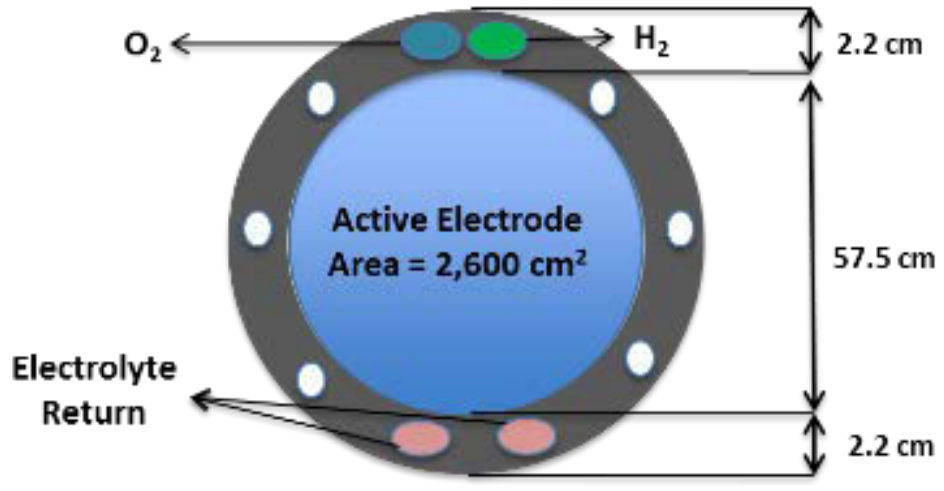

\begin{tabular}{l|l} 
Part & Materials
\end{tabular}
m-PBI

Electrodes Raney-nickel

Porous Transport Layer

Frame

Plates Nickel plates Pure Nickel Sheets PPS-40GF or PEEK

PVD: physical vapor deposition

PPS-40GF: poly Phenylene Sulfide (40\% Glass fiber filled)
Injection molding

${ }^{+}$See Vogt et al., 2014 Notes

Cast membrane using doctor-blade machine PVD + Leaching to get the required porosity Corrosion resistance in alkaline solution Surface treatment of high purity sheets 


\section{Accomplishment- PEM - Bipolar Plate Cost Model}

Nitriding or other special coating processes used to improve durability of bipolar plates in acidic environment

Case Hardening (Nitriding)
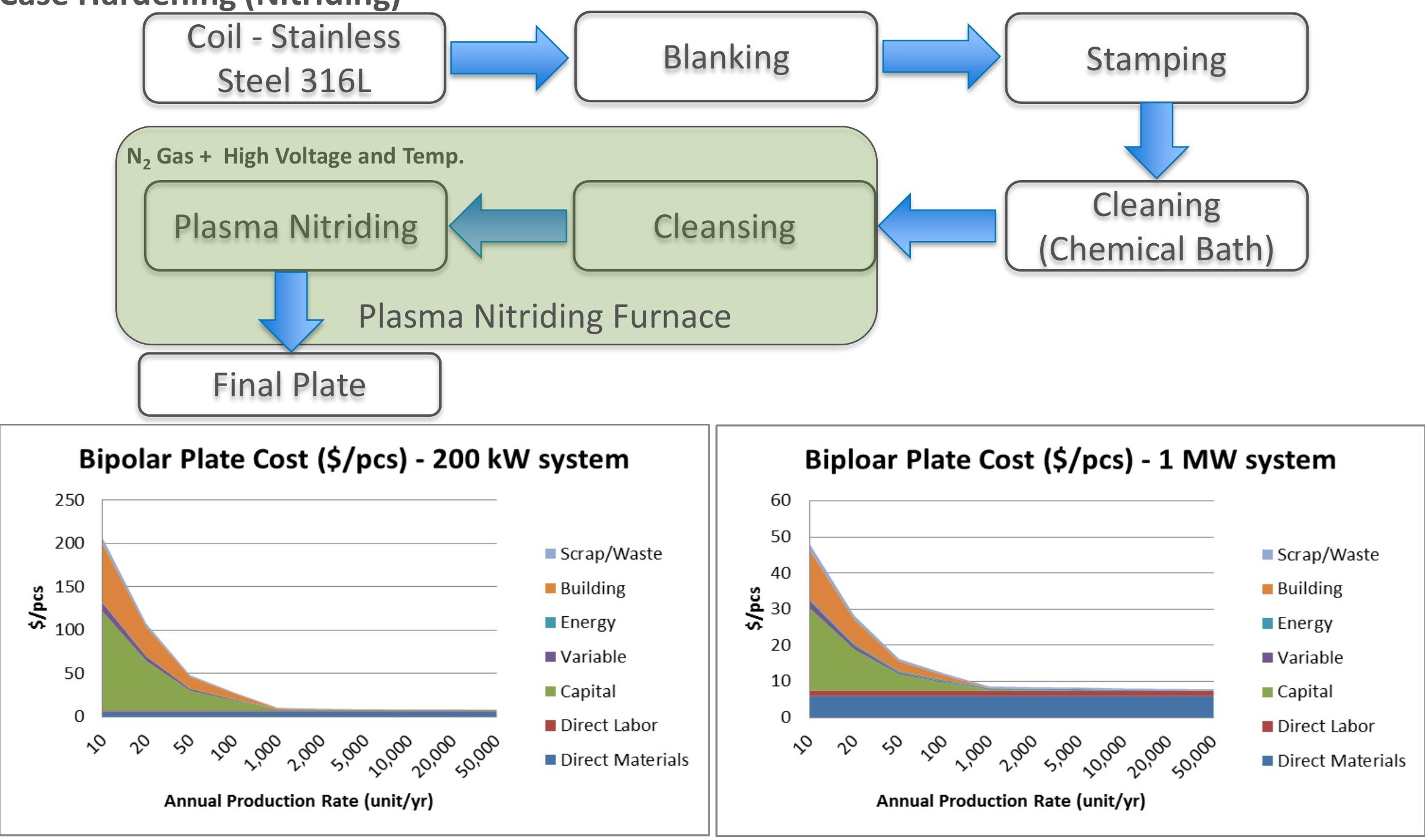


\section{Accomplishment- PEM Stack Assembly Cost Model}

Stack assembly is still semi-manual and there is good room for improvements (robots, flexible assembly line)

- Semi-Automatic assembly line

- 3 workers/line

- PPS-40GF Adhesive Materials for MEA

- Compression bands or tie rods

- Stainless steel 316L end plates (thickness 30 mm)

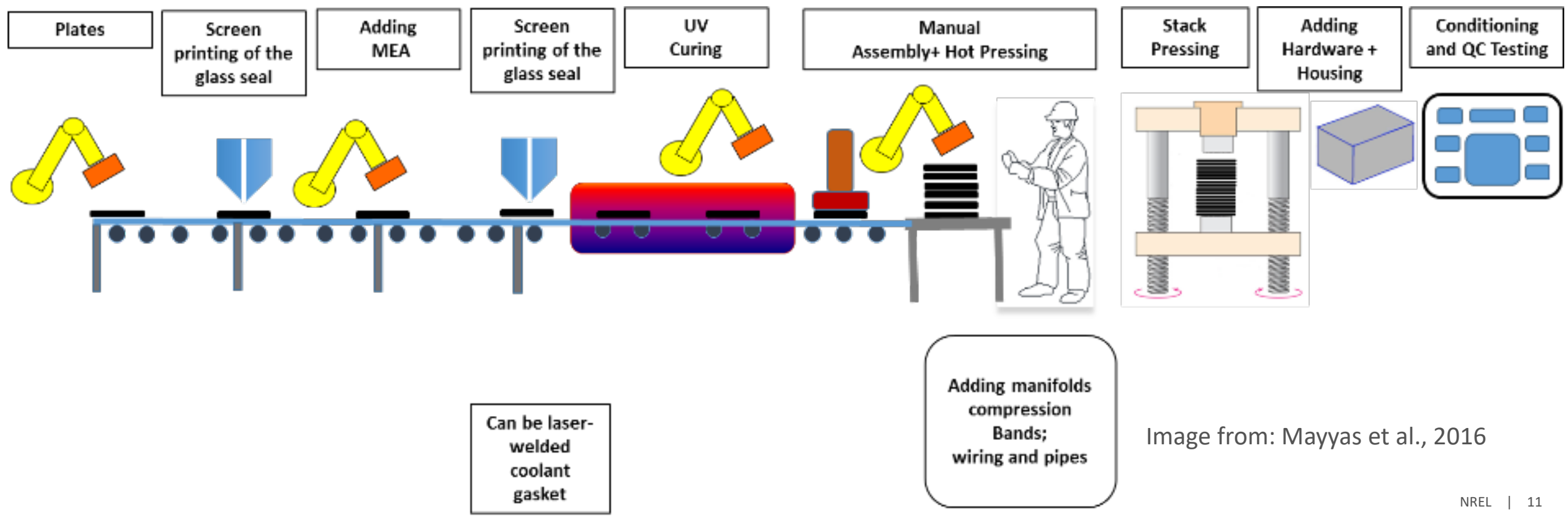




\section{Accomplishment- PEM Stack Assembly Cost Model}

Stack assembly is a labor-intensive process. Capital and building cost dominate at low production rates

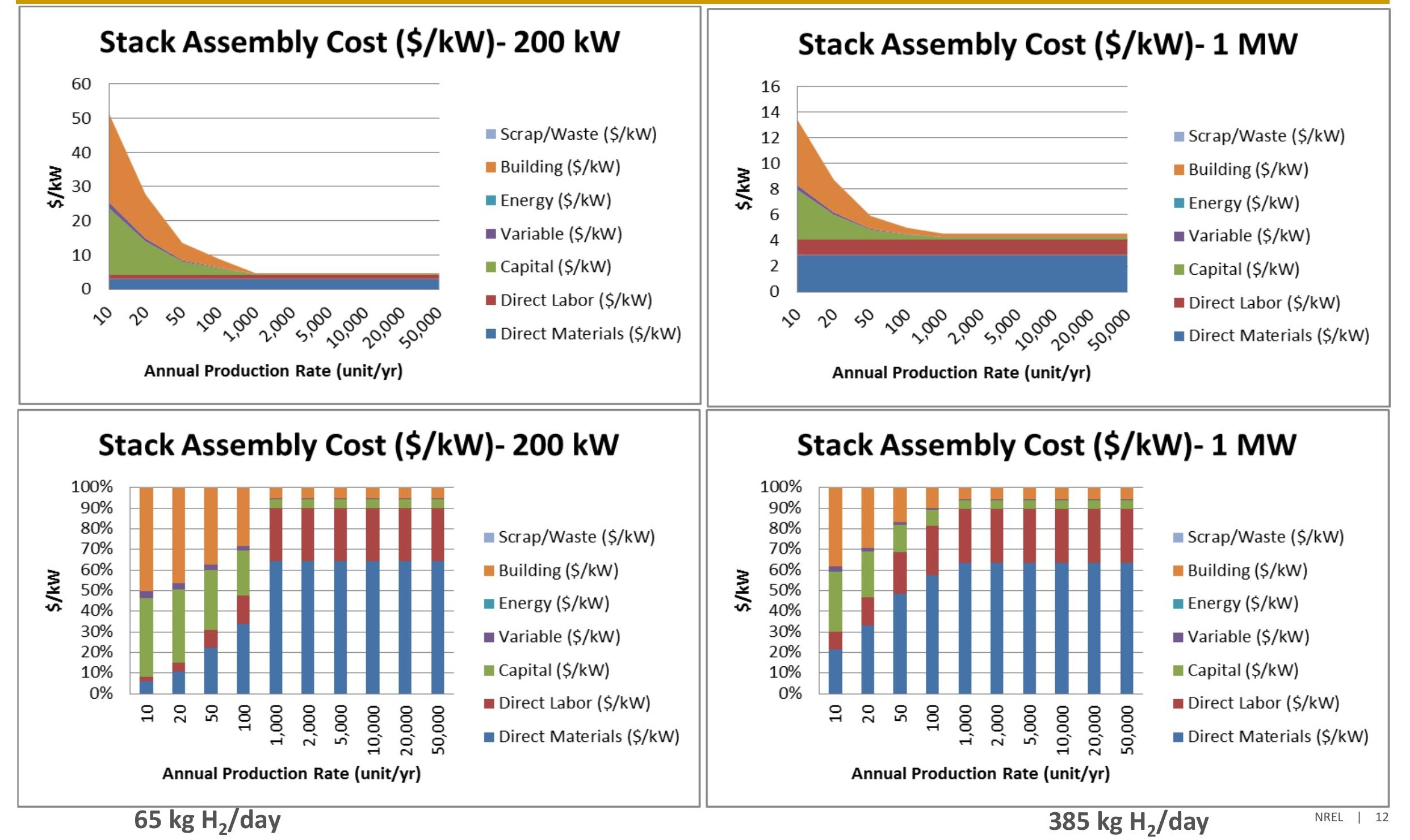




\section{Accomplishment- PEM Electrolyzer Stack Cost}

U.S. based manufacturers have advantages of 1 ) longer experience (i.e., learning rate), and 2) lower energy cost except for China and Mexico (still has smaller effect in the stack cost)

PEM Electrolyzer Stack Cost

(1 MW @ 10 unit/yr)

300

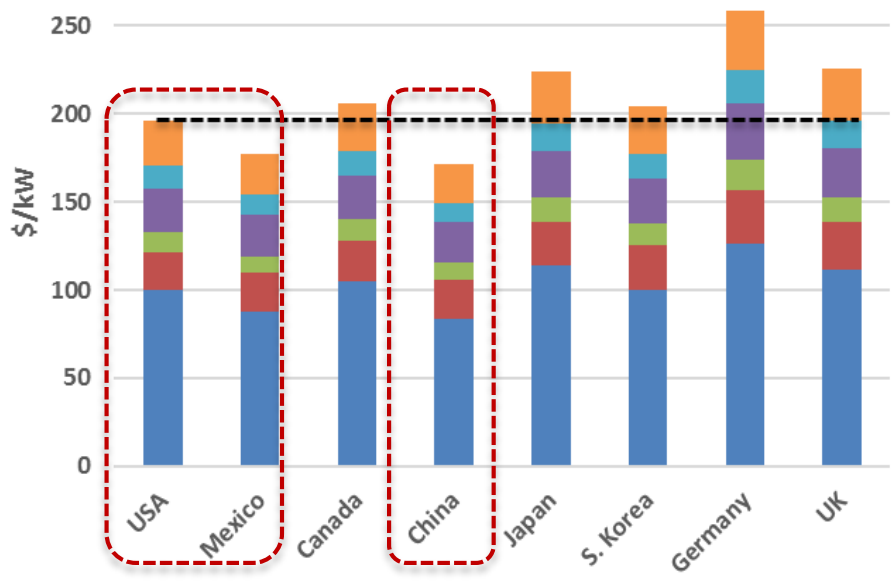

- China's advantage relative to the U.S. is driven by lower labor (including stack assembly), building, and energy costs

Balance of Stack

Assembly \& End-Plates

- Bipolar Plates

Erame

ص Porous Transport Layer

acM

$385 \mathrm{~kg} \mathrm{H}_{2} /$ day is driven by lower labor (including assembly), and building costs

PEM Electrolyzer Stack Cost

(1 MW @ 10 unit/yr)

300

- Relative cost of the stack is higher in Europe because of the higher labor and energy costs

- Relative cost of the stack is higher in Japan and Canada (in relative to U.S.) because of the higher labor costs

- Mexico's advantage relative to the U.S.

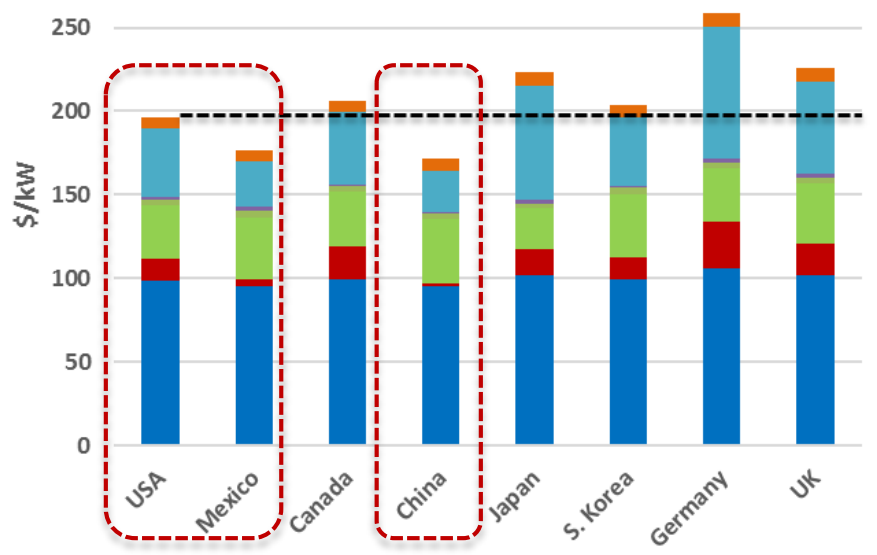

- Scrap/Waste (\$/kW)

nuilding (\$/kW)

n Energy (\$/kW)

- Variable (\$/kW)

napital (\$/kW)

- Direct Labor $(\$ / \mathrm{kW})$

- Direct Materials (\$/kW) 


\section{Accomplishment- PEM Electrolyzer Stack Cost}

\section{Larger production rates could also play role in reducing the cost (economies of scale for the stack modules) and balance of plant (not shown in these charts)}

PEM Electrolyzer Stack Cost

(1 MW @ 100 unit/yr)

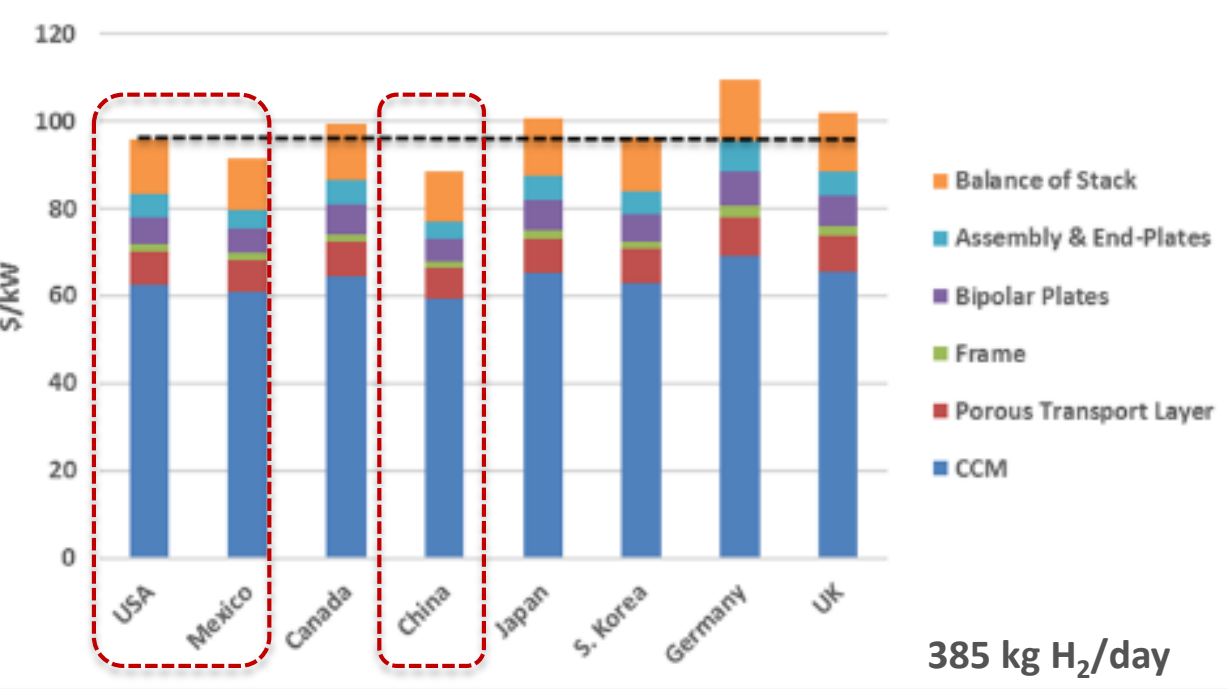

- $\quad$ China's advantage relative to the U.S. is driven by lower labor (including assembly), low material cost, building and energy costs

- Mexico's advantage relative to the U.S. is driven by lower labor (including assembly), and building costs

\section{PEM Electrolyzer Stack Cost}

(1 MW @ 100 unit/yr)

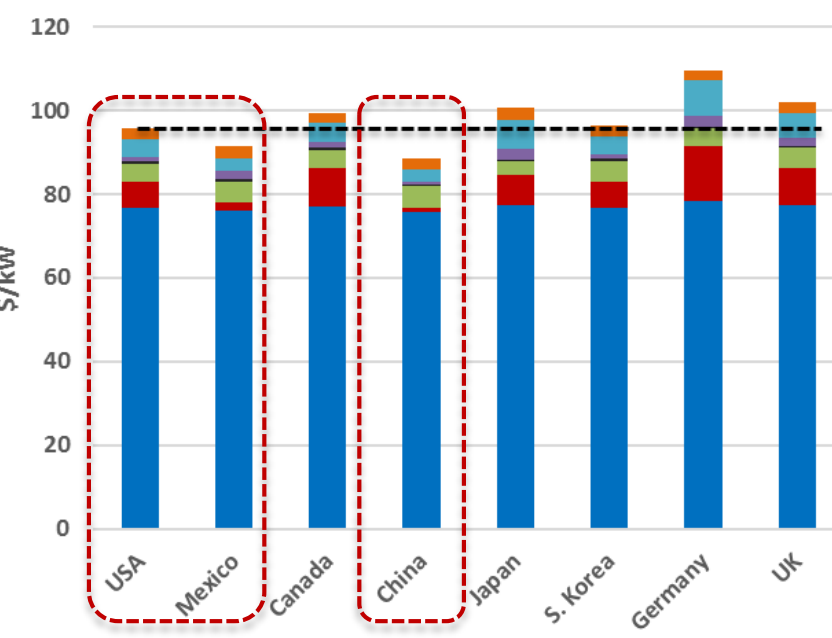

I Scrap/Waste (\$/kW)

nuilding (\$/kW)

- Energy (\$⿳/kW)

- Variable (\$/kW)

napital (\$/kW)

- Direct Labor $(\$ / \mathrm{kW})$

- Direct Materials $(\$ / \mathrm{kW})$ 


\section{Accomplishment- PEM Electrolyzer System Cost}

PEM Electrolyzer System Cost

(1 MW @ 10 unit/yr)

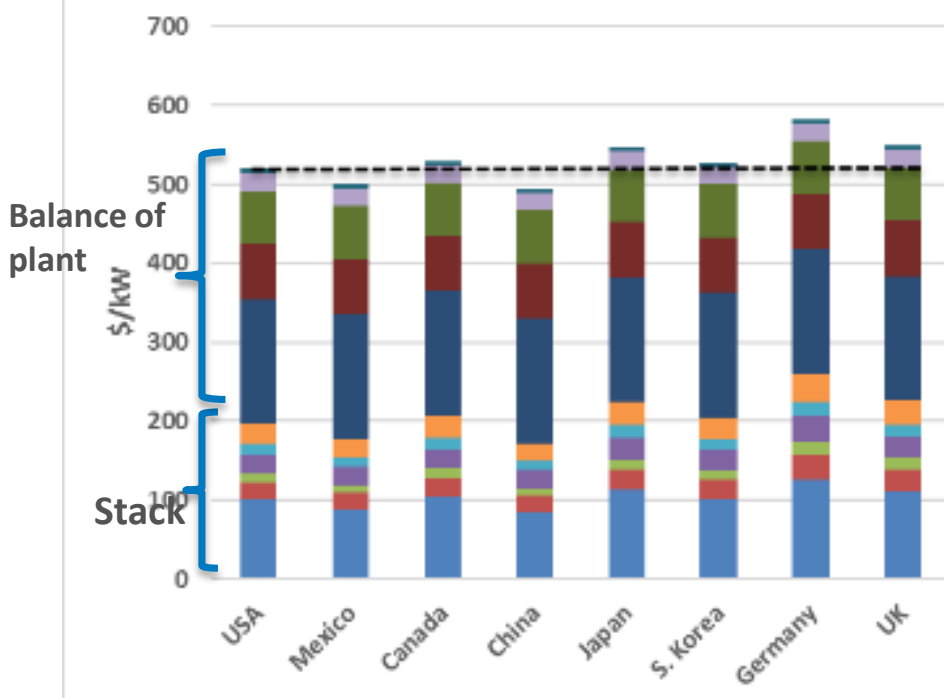

- Power electronics dominate the balance of plant cost (AC/DC rectifiers are very expensive compared to the DC/DC converter)

- Connecting electrolyzer to DC source (e.g., wind, PV) may reduce the cost of power electronics in the electrolysis system (e.g., AC-DC rectifier cost vs. DC-DC convertor cost)

\section{System cost by component (stack \& BOS)}

niscellanous

E Cooling

- Hydrogen Processing

- Deionized Water

Circulation

- Power Supplies

= Balance of Stack

- Assembly \& End-Plates

- Bipolar Plates

Erame

- Porous Transport Layer - CCM
- Unlike the stack, balance of plant is not manufactured in house and most of its parts are outsourced from reliable vendors

- Balance of plant shares $>50 \%$ of total system cost, and assumed to have same cost across all countries in the list
PEM Electrolyzer System Cost

(1 MW @ 100 unit/yr)

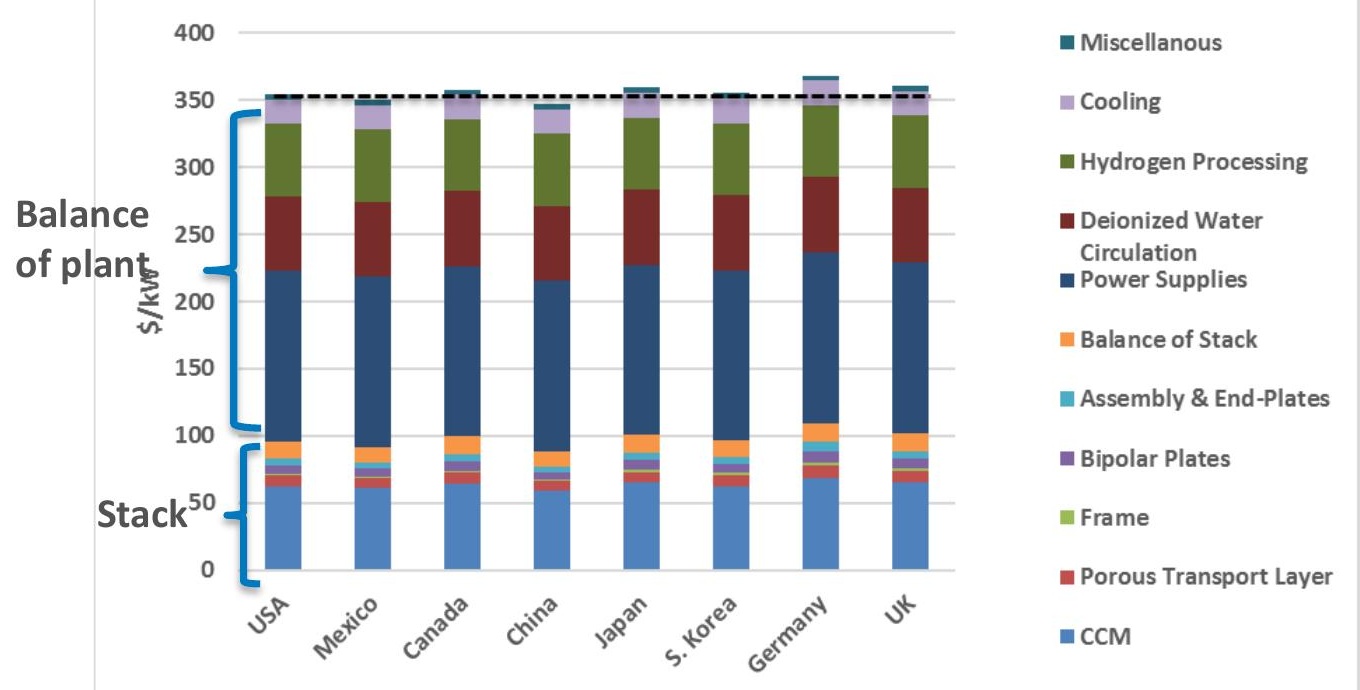




\section{Electrolysis Systems Value Chain}

\begin{tabular}{|c|c|c|c|c|c|}
\hline $\begin{array}{l}\text { Currently } \\
\text { Shipped }\end{array}$ & $\begin{array}{l}\text { Shipped } \\
\text { globally }\end{array}$ & Shipped globally & $\begin{array}{l}\text { Shipped } \\
\text { regionally }\end{array}$ & Shipped globally & $\begin{array}{l}\text { Shipped } \\
\text { globally }\end{array}$ \\
\hline $\begin{array}{c}\text { Value Share* } \\
\text { [Cumulative] }\end{array}$ & $\begin{array}{c}15 \% \\
{[15 \%]}\end{array}$ & $\begin{array}{c}7 \% \\
{[22 \%]}\end{array}$ & $\begin{array}{c}5 \% \\
{[27 \%]}\end{array}$ & $\begin{array}{c}73 \% \\
{[100 \%]}\end{array}$ & $\begin{array}{c}n / a \\
{[100 \%]}\end{array}$ \\
\hline
\end{tabular}

\begin{tabular}{|c|c|c|c|c|c|}
\hline $\begin{array}{c}\text { U.S. } \\
\text { Strengths }\end{array}$ & $\mathrm{n} / \mathrm{a}$ & $\begin{array}{ll}\text { - } & \text { R\&D Innovation } \\
\text { - } & \text { Manufacturing } \\
\text { experience } \\
\text { - } \\
\text { Educated } \\
\text { workforce }\end{array}$ & $\begin{array}{l}\text { Educated } \\
\text { workforce } \\
\text { - Synergistic } \\
\text { industries and } \\
\text { clustering } \\
\text { (benefiting from } \\
\text { fuel cell } \\
\text { manufacturing) }\end{array}$ & $\begin{array}{l}\text { Availability of } \\
\text { suppliers } \\
\text { Import and } \\
\text { export policies } \\
\text { (no tariffs) }\end{array}$ & $\begin{array}{l}\text { - Availability of } \\
\text { manufacturers } \\
\text { - Support from } \\
\text { federal and } \\
\text { state programs } \\
\text { (e.g., California } \\
\text { and Northeast } \\
\text { hydrogen } \\
\text { infrastructure) }\end{array}$ \\
\hline $\begin{array}{c}\text { Areas Need } \\
\text { Work }\end{array}$ & $\begin{array}{l}\text {-Supply chain } \\
\text { security for } \\
\text { critical } \\
\text { materials (e.g. } \\
\text { platinum, } \\
\text { Iridium, etc.) }\end{array}$ & $\begin{array}{l}\text { - Cost of } \\
\text { manufacturing } \\
\text { - Automation/ } \\
\text { advanced } \\
\text { manufacturing } \\
\text { (e.g., roll-to-roll) } \\
\text { - Low-cost labor } \\
\text { availability } \\
\text { (compared to } \\
\text { China and Mexico) }\end{array}$ & $\begin{array}{l}\text {-Quality and } \\
\text { performance of } \\
\text { products } \\
\text { - Cost of } \\
\text { manufacturing } \\
\text { - Automation of } \\
\text { assembly } \\
\text { process }\end{array}$ & $\begin{array}{l}\text {-Standardization of } \\
\text { parts } \\
\text { - Cost of power } \\
\text { electronics }\end{array}$ & $\begin{array}{l}\text { - Lack of } \\
\text { coordinated } \\
\text { incentives and } \\
\text { facilitation in } \\
\text { some states }\end{array}$ \\
\hline
\end{tabular}

* Assuming $1 \mathrm{MW}$ PEM electrolyzer system and 100 unit/yr production rate 


\section{Conclusions}

- Alkaline water electrolyzers have lower current and power densities, but have lower system cost (per kW basis) because of lower electrode materials cost (no precious materials) and larger cell size

- PEM electrolyzers have higher power density which requires smaller stack areas in relative to alkaline stack. This could contribute to lower stack costs with economies of scale

- U.S. based manufacturers have advantages of low energy cost, availability of skilled workers, and intellectual property

- Emerging manufacturing technologies (e.g. roll-to-roll catalyst coating, plates nitriding/coating, full automated assembly line, etc.) in association with economies of scale will have great impact on the capital cost of onsite $\mathrm{H}_{2}$ production systems and cost of $\mathrm{H}_{2}$ generation 


\section{Remaining Challenges and Barriers}

Our team is still working on several areas that could improve the impact of our analysis:

- Involve more organizations (industry, part suppliers, regulation agencies, etc.) in the hydrogen refueling station study

- Make new collaboration with industry in the ongoing project (manufacturing competitiveness analysis for onsite hydrogen production systems)

- Expand the cost study framework to cover CAPEX and OPEX and to compare cost of HRS to gas stations

- Benchmark our results with actual installations in several countries/regions

- There is a strong need to study manufacturing cost for balance of plant parts (e.g. AC-DC rectifier shares $>20 \%$ of total PEM electrolysis system cost) 


\section{Proposed Future Work}

- Complete manufacturing cost analysis onsite $\mathrm{H}_{2}$ production systems

- PEM electrolyzers

- Alkaline electrolyzers

- Study effect of emerging manufacturing technologies and economies of scale on the onsite hydrogen production systems capital cost and impacts on hydrogen production cost

- Study effects of the change in capital cost on the cost of hydrogen production (CAPEX \& OPEX)

- Benchmark our results with station installers and state/countries sponsoring new installations

"Any proposed future work is subject to change based on funding levels." 


\section{Responses to 2017 AMR Reviewer Comments}

There was no discussion about the cost of a "gasoline refueling station," which, although clearly less, is far from zero. It is interesting that gasoline is almost always dispensed from buried tanks, which are conveniently out of sight and have no footprint.

- Good point, this can be included in the total cost of ownership model in case we have time and resources to do so. Hydrogen tanks tend to be inconveniently large and troublesome. The polymer electrolyte membrane (PEM) electrolyzer costs were interesting, especially the cost variation with volume. It would have been interesting to include costs of contemporary commercial electrolyzers at times that high-current devices have some predictive insight into the scaling issue.

- Cost models for PEM and alkaline electrolysis are being developed and refined this year. New PEM electrolyzers with high pressure and/or current capabilities will be studied if time allows.

It is not clear how margin is applied/varies with manufacturing rate. The basis of manufacturing rate cost reduction (" $20 \%$ discount per 10x increase in purchased quantity") is not explained.

- This assumption is based on some discussions we had with fuel cell and $\mathrm{H}_{2}$ compressor manufacturers. It's sort of rule-of thumb and may not get a wider acceptance in the fuel cell community. Also, we found something similar to this assumption when we collected the quotes from different vendors with different discount ranging between 5$35 \%$ in most cases.

Dispenser cost analysis has focused on $\mathrm{H} 35$ and dual H35/H70. It is not clear why the team did not focus on single-hose dispenser H7O.

- H35 is still used for FC buses and trucks and H35/H70 is the current technology of dispensers which can fuel FCEV, FC-forklifts and FC-buses. $\mathrm{H70}$ single hose dispenser will be added to the analysis.

There is not enough industry participation. This would be helpful in understanding what market conditions would bring more players into these new markets. OPEX is not taken into account with CAPEX. For example, the DCHE may be more expensive, but refrigeration power costs could be greatly reduced. It is unclear how the project team would address this. The project seems to be wandering in many directions and should be focused on HRS costs.

- That's really good point. While we are focusing on manufacturing cost in this work, we think that OPEX is also important to consider in the total cost of hydrogen stations. We did include this in the work for electrolysis systems 


\section{Collaborations}

- David Hart, Franz Lehner, E4Tech, United Kingdom

- Provided data for manufacturing cost analysis for PEM and alkaline elctrolyzers

- Syed Saba, Forschungszentrum Jülich (FZJ), Germany

- Provided cost data for PEM electrolyzer to validate our cost model

- Brian James, Strategic Analysis Inc.

- Provided cost data for PEM electrolyzers

- Kevin Harrison, Bryan Pivovar, Guido Bender, Mark Ruth, Owen Smith, NREL

- Provided critical inputs for cost model and discussed cost model results

- Industry stakeholders: provided estimates for dispenser cost (AEG and Magna Power (power supplies), Grundfos (water pumps), etc.) 


\section{Summary}

- Relevance: to provide a framework for technoeconomic and supply chain analyses for hydrogen refueling stations and onsite hydrogen production systems

- Approach: Bottom-up cost analysis cost models and detailed supply chain maps.

- Technical Accomplishments and Progress:

- Manufacturing cost models for onsite hydrogen production systems (alkaline and PEM)

- Trade flow maps for global HRS's

- Collaboration: E4Tech, FZJ Institute

- Proposed Next-Year Research:

- Complete manufacturing cost models for alkaline electrolyzer

- Investigate effect of qualitative factors in the manufacturing competitiveness 


\section{Technology Transfer Activities}

- Not applicable for this cost analysis 


\section{Thank You}

\section{www.nrel.gov}

NREL/PR-6A20-71304 
Technical Back-Up Slides

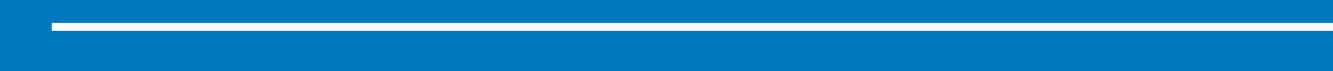




\section{Alkaline Electrolyzer System}

\section{Preliminary}

High Voltage Supply

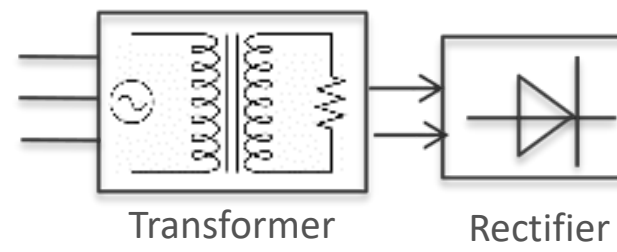

City

Water
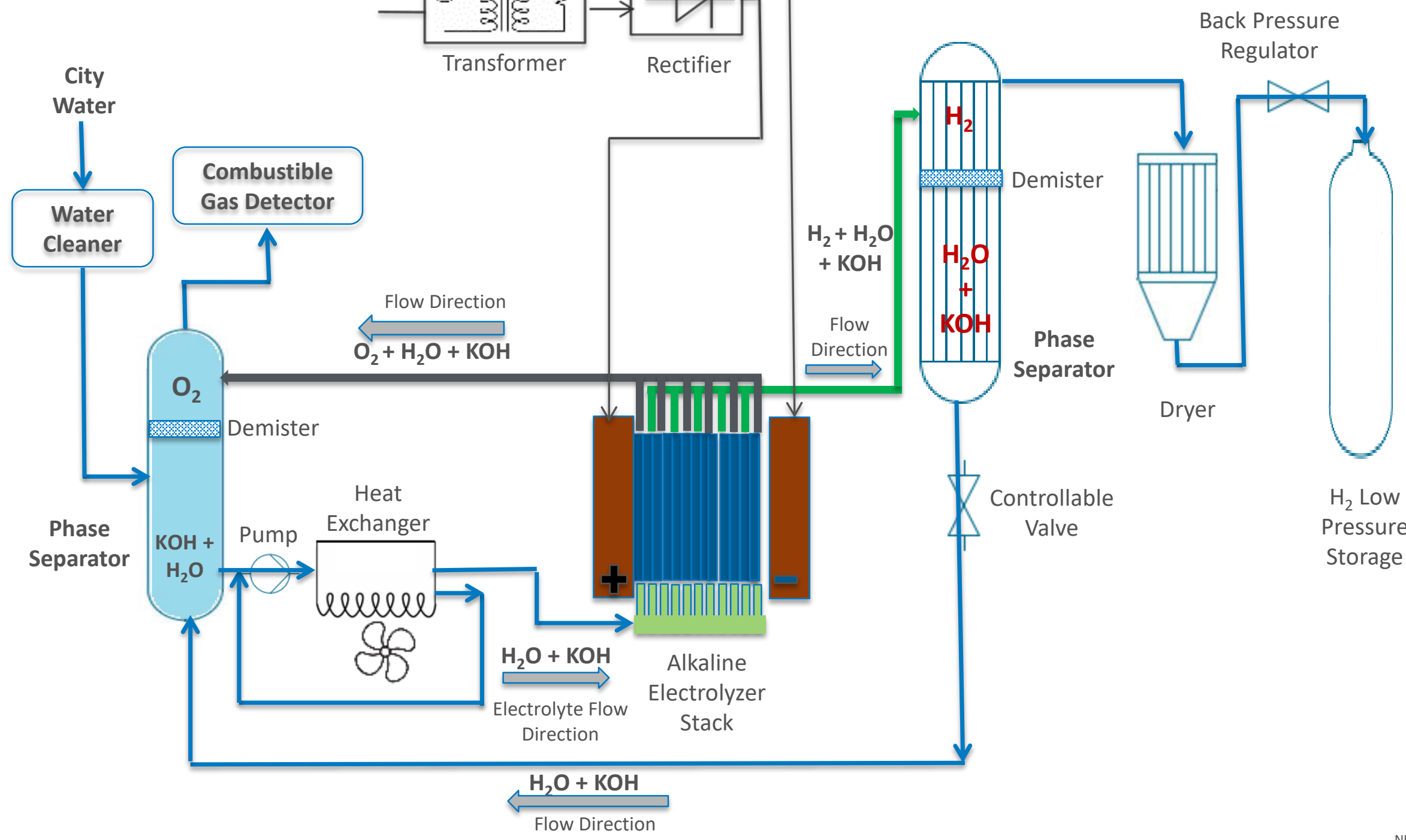

$\mathrm{H}_{2}$ Low

Controllable

Valve 


\section{Porous Transport Layer Cost (PEM Electrolyzer)}

Titanium layer performs better in the corrosive environment inside the stack. Could have lower cost at higher production rates

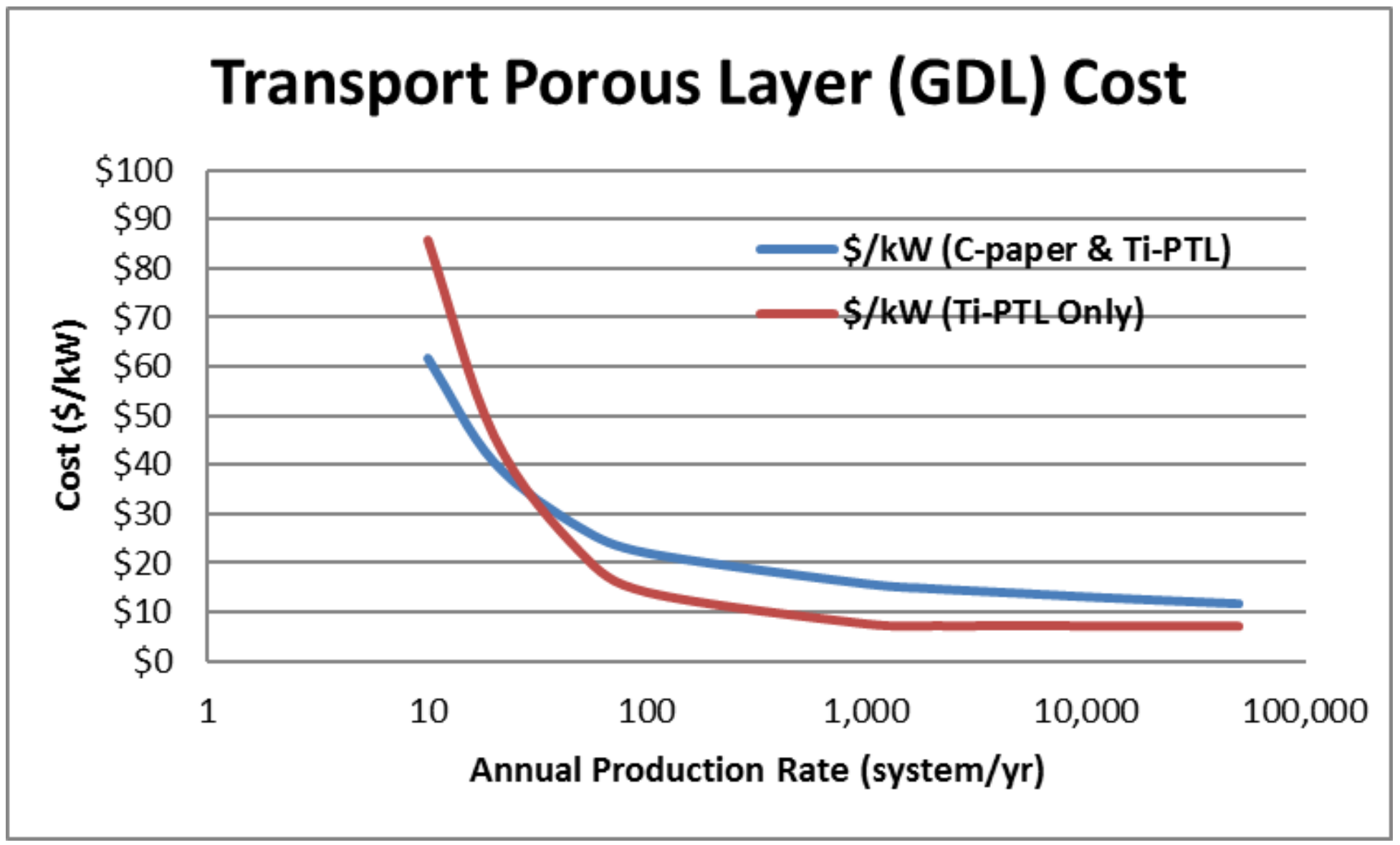

Cost curves for porous transport layers (also called GDL): 1) carbon paper on anode side and Ti-plate on cathode side, and 2) Titanium layer from both sides. Outsourced carbon layer, and Pt-PTL is manufactured in-house ( $30 \%$ porosity by volume).

Annual production rate represents number of produced electrolyzers per year ( $200 \mathrm{~kW}$ system) 


\section{Balance of Plant Cost -PEM (Parts Only)}

\section{Parts only at low order quantities. Discounts are expected with larger quantities}

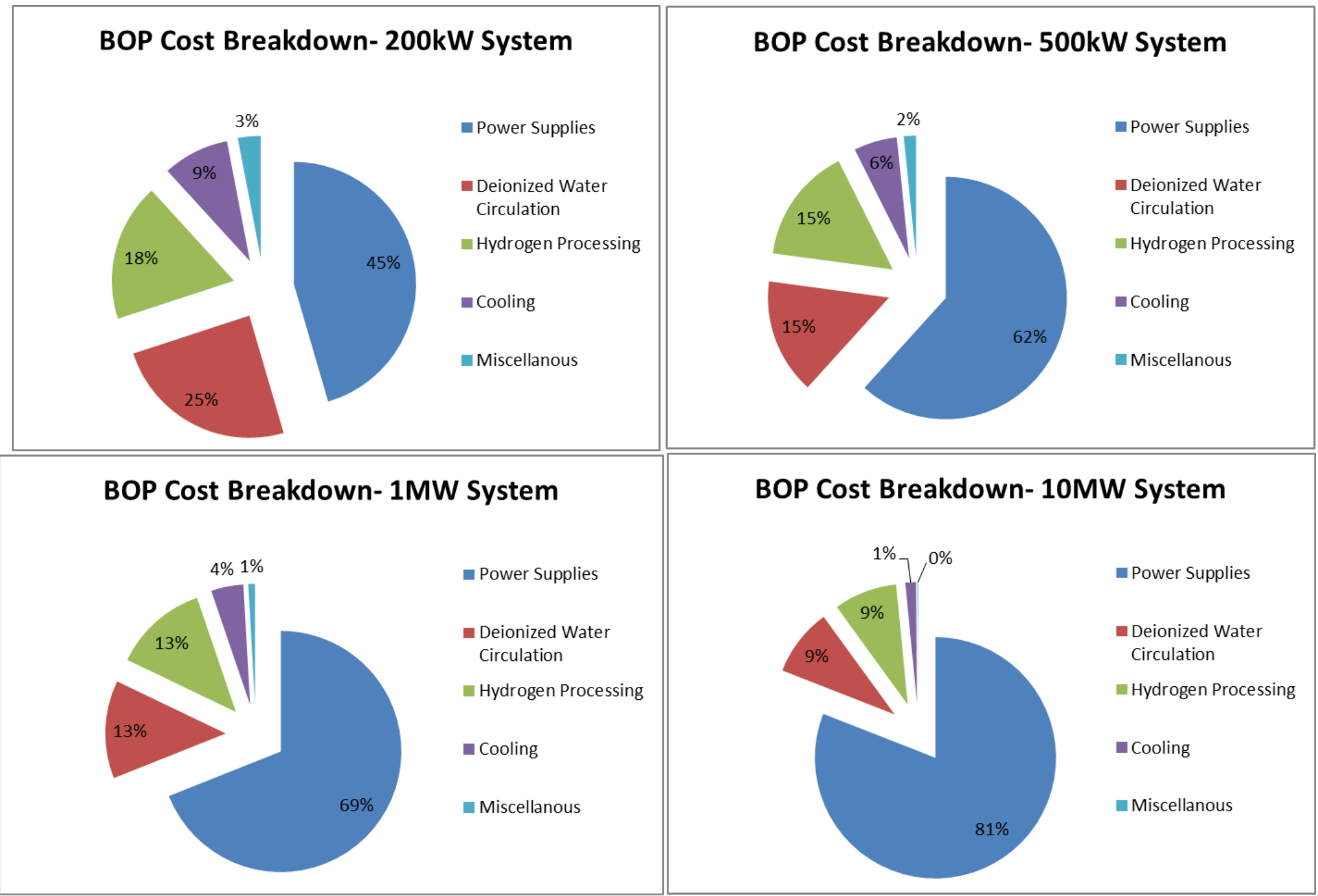




\section{Sensitivity Analysis - Alkaline Electrolyzer Stack}

$1 \mathrm{MW}$ Alkaline Electrolyzer Stack

(Cost = \$133/kW @ 10 units/yr)

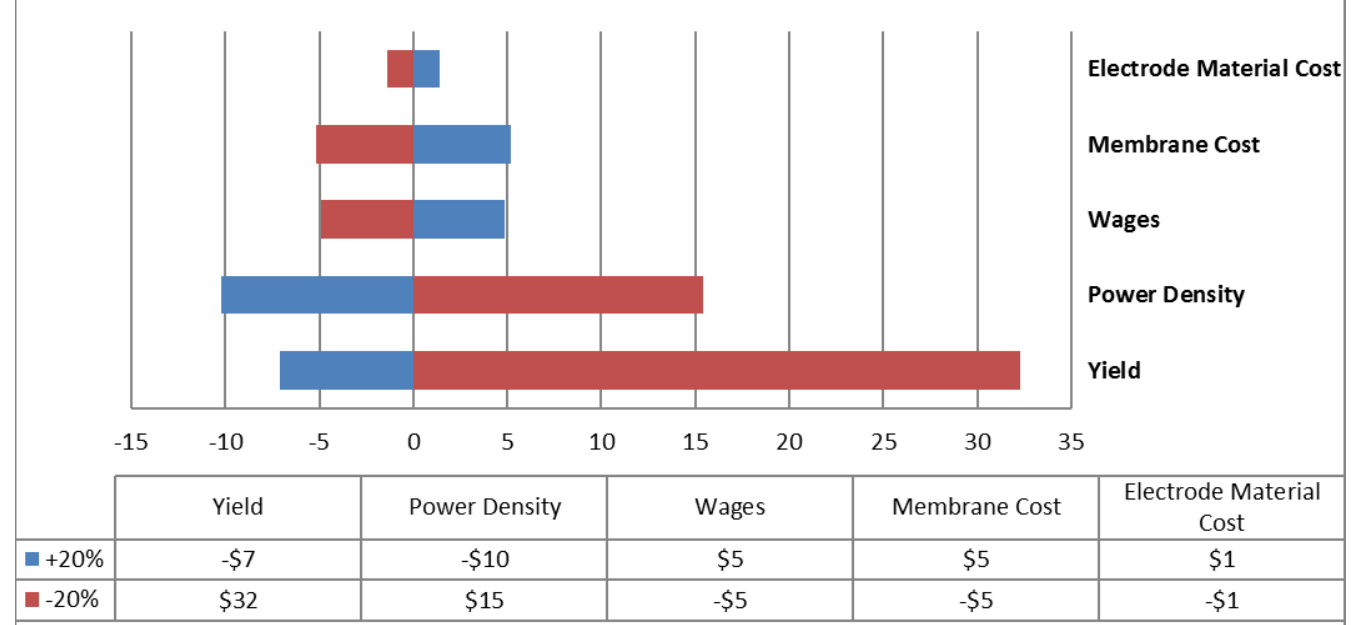

\section{Stack Only:}

- Yield (scrap rate) (Base=95\% for plates; $90 \%$ for membrane casting, $99.5 \%$ for stack assembly) dominates the stack cost at lower production rates

\section{Stack Only:}

- At higher production rates, power density and labor cost start to make larger impacts

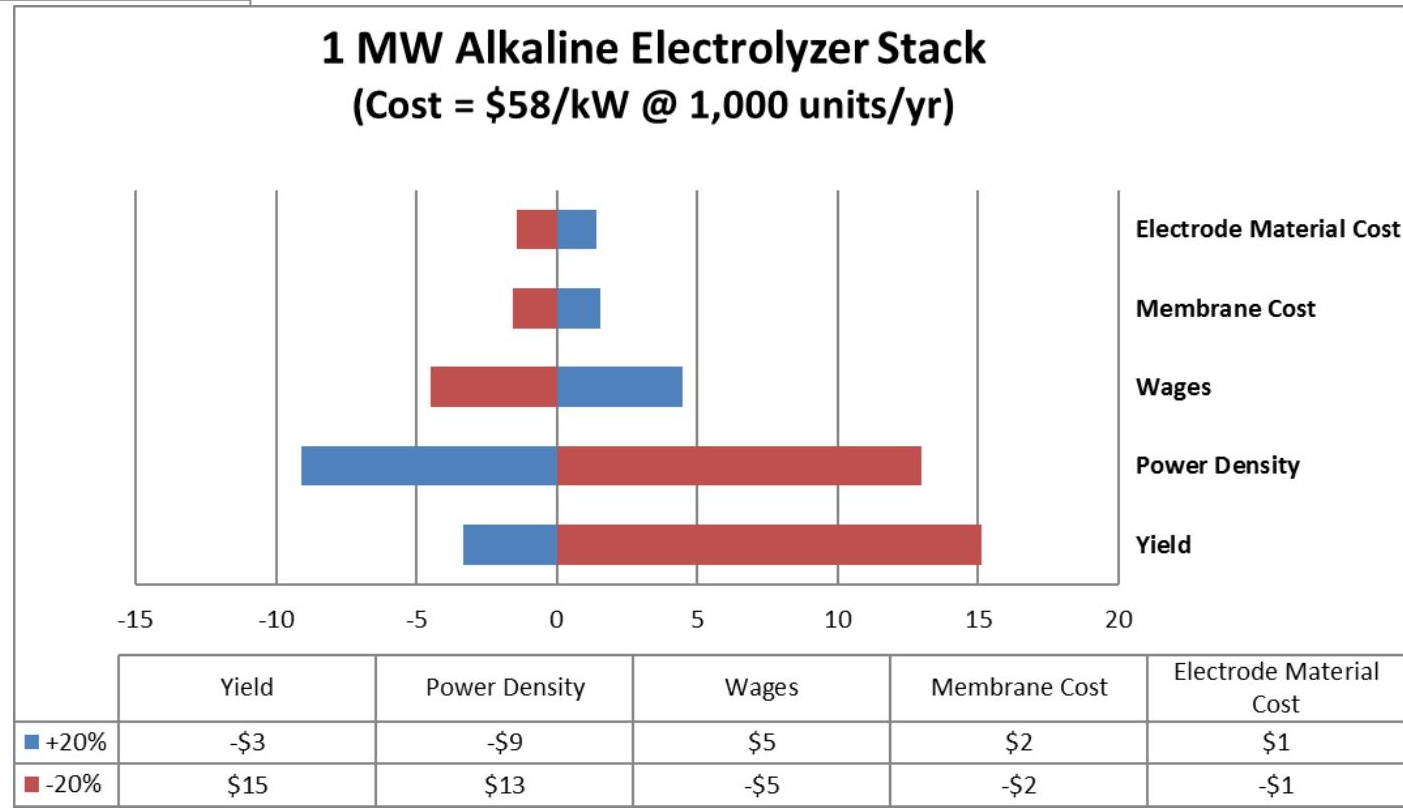

